\title{
Kesenian Kubrosiswo, Wahana Dakwah Petani Pedesaan Jawa
}

\author{
Agus Maladi Irianto \\ Fakultas Ilmu Budaya, Universitas Diponegoro \\ E-mail: ami.fibundip@gmail.com
}

\begin{abstract}
A farmer community in Javanese village, has developed art as an integrative need and, functionally, relates it to the culture in the area where they were living since long time ago. One of performing art has by a Javanese village farmer community that is still preserved till recently is Kubrosiswo. Kubrosiswo, is considered as one of the connector of ritual values with the concepts of simplicity and mutual cooperation between people in one farmer community.Kubrosiswo performing art is also identified as asocial activity namely slametan that is regularly done by Javanese farmers. The Javanese farmer community believes that slametan is able to accommodate social and ritual demand.
\end{abstract}

Keywords: Kubrosiswo, art, traditional, Javanese farmer

\section{Intisari}

Masyarakat petani pedesaan Jawa telah lama mengembangkan kesenian sebagai suatu kebutuhan integratif dan secara fungsional berkaitan dengan kebudayaan yang berlaku pada masyarakat tersebut. Salah satu kesenian masyarakat petani pedesaan Jawa yang sampai saat ini masih bertahan dan berkembang adalah kesenian Kubrosiswo. Kubrosiswo oleh masyarakat pendukung dianggap sebagai penghubung nilai-nilai ritual dengan konsep-konsep kesederhanaan dan kegotongroyongan di antara mereka sebagai masyarakat petani. Pertunjukan kesenian Kubrosiswo diidentikan sebagai kegiatan slametan yang selama ini dilakukan para petani di lingkungan kebudayaan Jawa. Masyarakat petani Jawa mempercayai bahwa slametan mampu mengakomodasi tuntutan sosial dan ritual.

Kata kunci: Kubrosiswo, kesenian, tradisional, petani Jawa

\section{Pendahuluan}

Kubrosiswo merupakan kesenian tradisional Kabupaten Magelang, Provinsi Jawa Tengah, Indonesia. Kabupaten Magelang merupakan salah satu kabupaten yang mempunyai ratusan kelompok kesenian tradisional yang hingga saat ini masih melakukan aktivitas. Berdasarkan wawancara dengan informan di Dinas Pendidikan dan Kebudayaan Kabupaten Magelang Tahun 2017 ini, sedikitnya wilayah ini menyimpan ratusan kelompok kesenian tradisional (1156 jenis kelompok) yang masih aktif (baik proses latihan maupun pertunjukan). Kubrosiswo adalah kesenian tradisional Kabupaten Magelang yang sejak lahir puluhan tahun lalu hingga sekarang masih hidup dan 
berkembang. Hampir setiap kecamatan yang ada di Kabupaten Magelang mempunyai kelompok kesenian Kubrosiswo (Irianto, Arido, dan Hermintoyo, 2016). Berdasarkan penelitian di lapangan hingga periode akhir tahun 2016, di Kabupaten Magelang sedikitnya ada 93 kelompok kesenian Kubrosiswo (selengkapnya dapat diperhatikan Tabel 01 berikut):

Tabel 01

Persebaran Kesenian Kubrosiswo Di Kabupaten Magelang

\begin{tabular}{|c|c|c|}
\hline No. & Nama Kecamatan & $\begin{array}{c}\text { Nama Kelompok } \\
\text { Kesenian Kubrosiswo }\end{array}$ \\
\hline 01 & Bandongan & Kubro Mino Muda, Siswo Mudo \\
\hline 02 & Borobudur & $\begin{array}{l}\text { Krido Siswo, Siswo Mudo, Ginar Siswa, Putra Jaya, Siswo } \\
\text { Mudo Bumen, Budi Siswo, Wargo Siswo, Bhumi Sembhara } \\
\text { Budaya, Bronto Mudo, Suka Siswo, Siswo Mudo Sumberrejo, } \\
\text { Wargo Mudo, Madyo Siswo }\end{array}$ \\
\hline 03 & Candimulyo & Krido Siswo \\
\hline 04 & Dukun & Mudo Budoyo, Bangun Mudo, Sari Siswo, Siwo Mudo \\
\hline 05 & Grabag & Bintang Siswo \\
\hline 06 & Kajoran & Sinar Remaja, Wargo Santoso \\
\hline 07 & Kaliangkrik & $\begin{array}{l}\text { Siswo Utomo, Hakaryo Iromo, Edi Siswo Bulusari, Edi Siswo } \\
\text { Wonosari, Kubro Budi Mulyo, Sarisiswo Madyo Utomo, Seni } \\
\text { Utomo, Sabo Gumboro }\end{array}$ \\
\hline 08 & Mertoyudan & $\begin{array}{l}\text { Suko Siswo, Tetro Siswo, Sinar Mudo, Andy Putro, Moncer } \\
\text { Siswo }\end{array}$ \\
\hline 09 & Mungkid & Siswo Mudo Cabean, Siswo Mudo Gondang, Bina Mudo \\
\hline 10 & Muntilan & $\begin{array}{l}\text { Panca Mudo, Siswo Mudo Cangkrang, Bnagun Muda, Sapta } \\
\text { Muda, Bronto Mudo, Transaca Muda, Siswo Mudo Bludru, } \\
\text { Kubro Seni Mudo, Siswo Mudo Semawe, Siswo Muda } \\
\text { Krandon, }\end{array}$ \\
\hline 11 & Ngablak & Siswo Mudo Keditan, Suryo Mudo \\
\hline 12 & Ngluwar & - \\
\hline 13 & Pakis & Siswo Mudo \\
\hline 14 & Salam & Sinar Siswo \\
\hline 15 & Salaman & $\begin{array}{l}\text { Margo Siswo, Kubro Seni Mudo. Panca Siswo, Siswo Mudo } \\
\text { Kedung, Suko Siswo Rukun Siswo }\end{array}$ \\
\hline 16 & Sawangan & $\begin{array}{l}\text { Suryo Mudo Kopeng, Setyo Muda, Argo Mudo, Konco Mudo, } \\
\text { Bangun Mudo, Permata Muda, Bintang Jaya, Sinar Mudo } \\
\text { Payakan, Rekso Mudo, Sinar Surya, Sinar Muda Ngentak, } \\
\text { Tunas Muda, Sinar Muda Kapuhan, Rukun Mudo, Karya Muda } \\
\text { Kenayan, Cahyo Eko Budaya, Sekar Siswo, Sekar Mudo, Karya } \\
\text { Muda Sobowono }\end{array}$ \\
\hline 17 & Secang & Siswo Mudo Krajan, Bintang Siswo, Asri Mudo, \\
\hline 18 & Srumbung & $\begin{array}{l}\text { Siswo Mudo Nggambrengan, Topeng Ireng Bina Muda, Krido } \\
\text { Mudo }\end{array}$ \\
\hline 19 & Tegalrejo & PKK Nurul Huda \\
\hline
\end{tabular}




\begin{tabular}{|l|l|l|}
\hline 20 & Tempuran & OR Elvita 92, Siswo Mudo Kiringan \\
\hline 21 & Windusari & $\begin{array}{l}\text { Rukun Siswa, Mugi Utomo, Mudhosono, Kesenian Rakyat } \\
\text { Islami }\end{array}$ \\
\hline
\end{tabular}

Sumber: Diolah dari data organisasi kesenian pada Dinas Pendidikan dan Kebudayaan Kab. Magelang 2016.

Bertolak dari gambaran tersebut pertanyaannya adalah, mengapa kesenian tradisional Kubrosiswo di Kabupeten Magelang masih berkembang hingga sekarang dan memuat fungsi apa sehingga masyarakat setempat masih mempertahankannya?

\section{Metode Penelitian}

Ada dua tahap yang peniliti lakukan dalam penelitian ini, yakni tahap review literature dan penelitian lapangan. Pada tahap review literature, peneliti mendapatkan sejumlah rujukan tentang data historis keberadaan Kubrosiswo di Indonesia. Referensi tersebut peneliti dapatkan dari jurnal, surat kabar, internet, makalah seminar, buku-buku teks, dan sejumlah laporan penelitian yang telah dilakukan peneliti sebelumnya. Setelah melakukan review literature, peneliti melakukan penelitian lapangan.

Pada tahap penelitian lapangan, peneliti melakukan pengumpulan data dengan cara melakukan observasi, wawancara mendalam dengan sejumlah narasumber yang dapat dijadikan pegangan dalam mendeskripsikan secara komprehensif tentang eksistensi kesenian tradisional Kubrosiswo. Observasi dimaksudkan membuat catatan dari seluruh keadaan dan kegiatan yang diamati, wawancara mendalam ditujukan kepada para informan kunci (key informant) yang dianggap mengetahui dan dapat memberikan informasi-informasi mengenai hakikat kesenian Kubrosiswo. Sedang untuk memahami faktor-faktor yang saling terkait dari data yang diperoleh tersebut, dikembangkan analisis berdasarkan pada kerangka pemikiran masyarakat yang dipelajari, dan bukan didasarkan pada ukuran peneliti (Denzin \& Lincoln, eds., 1994).

Sementara menyangkut analisis data, penelitian ini dilakukan dengan menggunakan metode pendekatan deskriptif analistis, yaitu pendekatan yang berusaha menggambarkan suatu hubungan antarfenomena dalam masyarakat (Creswell, 1994). Melalui metode pendekatan ini, penelitian akan mencari pemahaman mengenai alasan, latar belakang, serta makna-makna yang mendasari tindakan, pengambilan keputusan masyarakat pendukung menyikapi keberadaan kesenian Kubrosiswo. Data-data yang telah diperoleh tersebut kemudian diimplementasikan sebagai model-model, pandangan-pandangan, motivasi, 
sistem pengetahuan dan latar belakang masyarakat pendukung mengembangkan kesenian tradisional tersebut.

\section{Pembahasan}

Pada subbab ini dideskripsikan tentang keberadaan kesenian tradisional Kubrosiswo Kabupaten Magelang Provinsi Jawa Tengah menjadi dua hal. Pertama, latar belakang masyarakat pendukung kesenian kesenian tradisional Kubrosiswo, maupun persepsi dan respons masyarakat pendukung terhadap kesenian tradisional tersebut, Kedua, fungsi kesenian Kubrosiswo bagi masyarakat pendukungnya. Untuk menjelaskan masing-masing deskripsi itu, dapat diuraikan sebagai berikut.

\section{Latar Belakang Masyarakat Pendukung Kesenian Kubrosiswo}

Latar belakang masyarakat pendukung kesenian Kubrosiswo Kabupaten Magelang adalah masyarakat petani atau masyarakat yang bermatapencaharian sehari-hari dari dunia agraris. Berdasarkan data di lapangan, dari luas wilayah Kabupaten Magelang sebanyak 108.573 hektar, ternyata sekitar 80, 410 hektar merupakan lahan pertanian (baik berupa hutan, ladang, maupun persawahan). Dengan demikian, dapat dikatakan bahwa sekitar 80 persen masyarakat Kabupaten Magelang lebih dilatarbelakangi oleh dunia pertanian. Di samping dilatarbelakangi dunia pertanian, masyarakat Kabupaten Magelang berlatarbelakang nilainilai religius yang kuat, terutama pengaruh agama Islam (Irianto, 2017). Nilai-nilai religius yang kuat pengaruh agama Islam tersebut, dibuktikan dengan adanya ratusan pondok pesantren (126 buah) yang tersebar pada 21 kecamatan wilayah tersebut. Menurut keterangan sejumlah informan, kesenian Kubrosiswo mulai muncul pada tahun 1960-an, bersamaan dengan maraknya paham komunis yang waktu itu mendominasi masyarakat di sekitar Mendut-Mungkid Kabupaten Magelang.

Dengan latar belakang masyarakat petani dan didukung dengan peran serta tokoh agama di sejumlah pondok pesantren yang tersebar pada 21 kecamatan yang ada itulah, kesenian tradisional Kubrosiswo lahir dan berkembang hingga saat ini. Masyarakat pendukung mengembangkan Kubrosiswo, karena melalui kesenian tersebut mempertahankan identitasnya (Irianto, Arido, dan Hermintoyo, 2016). Ketika kesenian tradisional itu dapat dijadikan wahana mempertahankan identitas, maka masyarakat 
pendukung akan senantiasa mewariskannya kepada generasi berikutnya baik secara lisan atau melalui praktek langsung.

Kesenian Kubrosiswo merupakan seni pertunjukan berupa tarian yang diperankan oleh sekitar 25 orang penari dengan menampilkan sejumlah komposisi gerakan tari barisberbaris. Pada awalnya semua penari Kubrosiswo adalah laki-laki, namun pada perkembangannya kini terlibat pula penari perempuan. Tarian tersebut diiringi alat musik pengiring yang pada awalnya hanya menggunakan alat musik akustik tradisional seperti suling, jedhor, bedug, kendang, dan bendhe. Namun sejalan dengan tuntutan hiburan serta variasi lagu yang dimainkan, pengiring tarian Kubrosiswo juga menggunakan alat musik seperti organ, gitar dan drum. Durasi pertunjukan Kubrosiswo sekitar tiga jam.

Kesenian tradisonal Kubrosiswo, menurut keterangan sejumlah informan, merupakan seni akulturasi Jawa, Islam, dan Kolonial. Hal Itu dapat dilihat dari kostum yang dikenakan para pemain. Para pengiring musik misalnya, mayoritas laki-laki beskap (baju adat lengan panjang etnis Jawa) dengan blangkon (topi adat etnis Jawa). Sedangkan, penari perempuan mengenakan hijab atau kerudung (pakaian penutup kepala perempuan muslimah). Kendati di bagian atas mereka mengenakan pakaian adat etnis Jawa, atau juga bertutup kepala Islami. Namun kostum yang dipakai masing-masing pemain pada bagian pinggang ke bawah mengenakan seperti layaknya pemain sepak bola. Selain sejumlah kostum tersebut, terdapat satu atau dua pemain laki-laki yang berfungsi sebagai penyanyi. Si penyanyi ini mengenakan kostum seorang kapten tentara Kolonial Belanda yang dianggap sebagai pemimpin tarian dan selalu membawa peluit. Fungsi peluit sebagai penanda mengawali dan sekaligus mengakhiri setiap gerakan tari pada setiap komposisi (Irianto, Arido, dan Hermintoyo, 2016).

\section{Fungsi Kesenian Kubrosiswo Bagi Masyarakat Pendukungnya}

Seperti yang telah dideskripsikan pada uraian di atas, hakikat dan fungsi kesenian Kubrosiswo pada dasarnya berkaitan erat dengan latar belakang masyarakat pendukung menyikapi kesenian tersebut. Sebagai masyarakat petani misalnya, mereka mempertahankan dan mengembangkan kesenian tradisonal Kubrosiswo sebagai suatu kebutuhan integratif dan secara fungsional berkaitan dengan kebudayaan yang berlaku pada masyarakat tersebut.

Berdasarkan wawancara dengan sejumlah informan, masyarakat pendukung mempertahankan kesenian Kubrosiswo, karena sejak lama mereka terikat dalam suatu 
ikatan tradisi dan perasaan. Dengan terus memegang tradisi dan perasaan itulah, maka mereka menganggap bahwa dunia pertanian dan berkesenian merupakan bagian yang saling berhubungan erat. Mereka bekerja di sawah bukan semata-mata untuk mencari keuntungan, tetapi lebih cenderung untuk mencukupi keperluan keluarganya yang sederhana atau hak untuk hidup pada paras subsistens (Irianto, Suharyo, dan Hermintoyo, 2015). Hal itu berkatian dengan pengetahuan masyarakat petani pada dasarnya lebih bersifat sosial daripada ekonomi. Temuan menyebutkan bahwa nilai dan sikap masyarakat petani cenderung lebih mengutamakan ketenteraman dan kedamaian tanpa harus memaksakan keinginan lebih daripada yang mereka miliki selama ini (Irianto dan Thohir, 2004).

Di sisi lain, seperti yang diungkapkan sejumlah informan, Kubrosiswo adalah kesenian tradisional yang berlatar belakang penyebaran agama Islam di Pulau Jawa. Secara etimologis "kubro" berarti besar dan "siswo" berarti siswa atau murid. Sehingga dapat diartikan murid-murid Tuhan yang diimplementasikan dalam pertunjukan yang selalu menjunjung kebesaran Tuhan. Secara terminologis Kubrosiswo merupakan singkatan dari "Kesenian Ubahing Badan lan Rogo"atau kesenian yang menggerakan badan dan jiwa, yang bermakna bahwa manusia harus hidup seimbang antara keperluan dunia dan akhirat (Irianto, Arido, dan Hermintoyo, 2016).

Melalau syair-syair yang dilantunkan penyanyi Kubrosiswo, pesan dakwah kesenian tradisional itu disampaikan. Salah satunya adalah syair berbunyi sebagai berikut:

"Poro Muslimin podo bungah

Puji syukur ing Gusti Allah

Sasi rejeb tanggal pitu likur

Allah animbali kanjeng Rosul

Nabi Muhammad kedawuhan

Anindaake marang kewajiban

Nindaake sholat 50 waktu

Kanggo sangune nyuwun pangestu

50 waktu mung kari limo

Kanggo ngenteng-ngenteng poro manungso

Sholat iku wajibe kang mulyo

Ora abot lan ora rekoso"

(Para Muslimin sama senang

Puji syukur kehadirat Allah

Bulan rajab tanggal 27

Allah memanggil Rasulullah

Nabi Muhammad menerima perintah 
Menjalankan kepada kewajiban

Menjalankan sholat 50 waktu

Buat bekal meminta restu (saat kita mati)

50 waktu tinggal lima

Untuk meringankan semua manusia

Sholat itu kewajiban yang mulya

Tidak berat dan tidak menyulitkan)

Setelah itu, sang penyanyi melanjutkan dengan syair sebagai berikut:

“...Dengarkanlah saudara-saudaraku// Aku akan bercerita padamu// Menerangkanlah rukun agamamu//Agar saudara siapa tahu// Lima perkara banyak rukun Islam// Agama suci di seluruh alam// Ashaduala iilaha illallah// Serta Muhammad utusan Allah// Rukun pertama selesai sudah// Kedua kali mendirikan sholat// Lima kali sehari beribadah dengan pernah membaca kalimah// Membayar zakat rukun yang ketiga// Sesudah cukup seni sehartanya// Puasa Ramadhan yang keempatnya// Dari awal sampai hari raya// Sekarang satu lagi penghabisan// Pergi ke Makkah mencari kesempurnaan// Sudah cukuplah agaknya sekian// Salam dan maaf kami ucapkan...”

Berdasarkan sejumlah wawancara dengan sejumlah informan, bahwa hakikat pertunjukan kesenian tradisional Kubrosiswo adalah sebagai ekspresi jiwa dan tingkah laku manusia, yang tertuang melalui bentuk gerakan anggota tubuh. Kesenian tradisional itu dipergelarkan karena ia merupakan salah satu ekspresi estetik manusia untuk memenuhi kebutuhan integratif (Coates, 2017: 7-21). Pemenuhan kebutuhan integratif muncul karena ada dorongan pada diri manusia yang secara hakiki senantiasa ingin merefleksikan keberadaannya sebagai makhluk yang bermoral, berakal, dan berperasaan. Kubrosiswo oleh masyarakat pendukung dianggap sebagai penghubung nilai-nilai ritual dengan konsep-konsep kesederhanaan dan kegotongroyongan di antara mereka sebagai masyarakat petani. Pertunjukan kesenian Kubrosiswo diidentikan sebagai kegiatan slametan yang selama ini dilakukan para petani di lingkungan kebudayaan Jawa. Masyarakat petani Jawa mempercayai bahwa slametan mampu mengakomodasi tuntutan sosial dan ritual (Irianto, 2016: 2355-3820).

Kubrosiswo adalah kesenian tradisional yang berlatar belakang penyebaran atau dakwah agama Islam, di Indonesia. Penyebaran agama Islam di Indonesia berbeda dengan dengan tata cara yang dilakukan di jazirah Arab. Persentuhan antara tiga hubungan kepercayaan pra Islam (animisme, Hindu dan Budha) tetap hidup mewarnai Islam dalam pengajaran dan aktivitas ritual pemeluknya. Hal itu terjadi, akulturasi ajaran Islam dengan nilai-nilai kebudayaan lokal. Inilah bentuk interkoneksi antara ajaran Islam dengan kearifan lokal (Jailani, 2014:413-432). 
Proses akulturasi merupakan konsep untuk menggambarkan proses panjang bertemunya dua atau lebih tata nilai antara Islam dengan nilai-nilai lokal di mana individu, kelompok dan masyarakat bertempat tinggal dengan budaya yang telah dimilikinya. (Widiana, 2015: 198-215). Pertunjukan kesenian tradisional dan ekspresi lokaltradisional dalam dakwah Indonesia telah membentuk pencarian nilai-nilai luhur Islam Indonesia secara signifikan (Suwarno, 2014: 253-278). Demikian pula berdasarkan penelitian Pujiati (2012: 114-117), lirik-lirik lagu kesenian tradisional Kubrosiswo, pada dasarnya memuat tiga kategori pesan dakwah yaitu: pesan akidah, pesan syari'ah, dan akhlak.

Hasil observasi dan wawancara dengan sejumlah informan menjelaskan bahwa hakikat dan fungsi kesenian ini selain sebagai hiburan yang mampu memenuhi kebutuhan integratif, ia juga memuat unsur dakwah keagamaan yang mampu mengakomodasi nilainilai spiritual dan religiusitas masyarakat pendukung. Untuk itulah, masyarakat pendukung Kubrosiswo yang mayoritas bermata pencaharian sebagai petani secara turun termurun mempertahankan dan mewariskan kepada generasi berikutnya (Irianto, Arido, dan Hermintoyo, 2016).

\section{Kesimpulan}

1. Kubrosiswo adalah salah satu kesenian tradisional yang cukup populer di Kabupaten Magelang, Provinsi Jawa Tengah, Indonesia. Kesenian tradisional ini, selama ini lebih disikapi sebagai bagian dari dunia agraris dan ekspresi religiusitas masyarakat pendukungnya. Fungsi kesenian ini selain sebagai hiburan masyarakat petani, ia juga memuat unsur dakwah keagamaan.

2. Kubrosiswo oleh masyarakat pendukung hingga saat ini masih berkembang dan dipertahankan, karena ia dianggap sebagai kebutuhan integratif sekaligus penghubung nilai-nilai religiusitas dengan konsep-konsep kesederhanaan dan kegotongroyongan masyarakat petani Jawa. Pertunjukan kesenian Kubrosiswo diidentikan sebagai kegiatan slametan yang selama ini dilakukan para petani di lingkungan kebudayaan Jawa. Masyarakat petani Jawa mempercayai bahwa slametan mampu mengakomodasi tuntutan sosial dan ritual. 


\section{Daftar Pustaka}

Coates, Emily (2017). "The Poetics of Physics in Dance". PAJ: A Journal of Performance and Art. 39 (2): 7-21.

Creswell, John W. (1994). Research Design. Qualitative \& Quantitative Approaches. USA: SAGE Publication.

Denzin, Norman K. \& Lincoln, Y.S. ,eds.(1994). Handbook of Qualitative Research. USA: SAGE Publication.

Irianto dan Thohir, M. (2004). "Ekosistem Dieng dan Kebijakan Daerah Kabupaten Wonosobo" . (Laporan penelitian). Semarang: Puslit Sosbud LPPM Undip

Irianto, Agus Maladi, Suharyo, dan Hermintoyo. (2015). "Mengemas Kesenian Tradisional Dalam Bentuk Industri Kreatif, Studi Kasus Kesenian Jathilan" (laporan penelitian). Semarang: LPPM Undip.

Irianto, Agus Maladi. (2016). "The Development of Jathilan Performance as an Adaptive Strategy Used by Javanese Farmers". Dimuat dalam Jurnal Harmonia 16 (1): 2355-3820.

Irianto, Arido, dan Hermintoyo. (2016). "Marjinalisasi Kesenian Tradisional Dari Tuntutan Industri Pariwisata, Strategi Komodifikasi Budaya Di Era Global". (Laporan penelitian). Semarang: LPPM Undip.

Irianto, Agus Maladi. (2017). "Kabupaten Magelang, Menuju Kota Masa Depan". Disampaikan pada Seminar Ulang Tahun Kabupaten Magelang, 29 Maret 2017 di Pedopo Kabupaten Magelang.

Jailani, Imam Amrusi. (2014)." Dakwah dan Pemahaman Islam di Ranah Multikultural". Jurnal Penelitian Sosial Keagamaan Walisongo. 22 (2) :413-432

Pujiati, Ning. (2012). "Pesan-Pesan Dakwah Dalam Syair Kubrosiswo". (Skripsi). Semarang: Fakultas Dakwah Institut Agama Islam Negeri Walisongo

Suwarno, Peter. (2014). "An Islamic Search Of Noble Values: The Prevalence of Modern Principles and the Resilience of Local Traditions in Indonesian Da'wa. Jurnal Penelitian Sosial KeagamaanWalisongo. 22 (2): 253-278.

Widiana, Nurhuda. (2015). "Pergumulan Islam dengan Budaya Lokal: Studi Kasus Masyarakat Samin di Dusun Jepang Bojonegoro". Jurnal Teologia. 26 (2): 198215 